\title{
Drama Gösterilerinin Değerlendirilmesi
}

\author{
Ayșe OKVURAN \\ Ankara Üniversitesi ${ }^{1}$
}

\section{Özet}

Bu araştırmanın amacı Ankara'daki okulöncesi eğitim kurumlarındaki drama gösterilerinin genel bir değerlendirmesini yapmaktır. Araştırmanın çalışma grubu 2005-2008 yılları arasında anaokullarında ya da anasınuflarında yapılan yedi drama gösterisi oluşturmaktadır. Araştırma verileri drama ögretmenlerinin izniyle video kayltlart yapılarak elde edilmiştir. Yedi drama gösterisi alandan dört uzman tarafindan kategoriler oluşturularak değerlendirilmiştir. Bu kategorilerin olumlu, olumsuz, karışılk ve nötr olarak duygusal yön analizleri yapılmıştır. Dört uzmanın ayrı ayrı ve aynı anda yaptzklarl değerlendirmeleriyle geçerlik ve güvenilirlik belirlenmiştir. Araştırma sonucunda Ankara'daki okulöncesi kurumlarındaki drama gösterisi, oyunun akışı, oyuncuların katılarak oynaması, oyunun konusu, oyuna içeriden müdahale, oyundaki boşluklar ve liderin oyuna katılımı kategorilerinde olumlu, oyunun ezbere dayalı olması, doğaçlamanın yer alıp almaması, bedeni kullanma, didaktiklik açısından olumsuz bulunmuştur. Oyunlardaki dansların oyuna uygunluğu, oyuncuların sahnedeki rahatlığl, oyunun dili, oyuncuların bedenini kullanması, oyunun mesajı açısından karışık olarak yorumlanmıştır. Bu araştırma yedi drama gösterisinin görsel ve sözel dilinin içerik analizi için ön çalışma niteliğindedir.

Anahtar sözcükler: Eğitimde drama, drama gösterisi

\begin{abstract}
The purpose of this study is to evaluate drama performances in early childhood institutions in Ankara. This study is made up seven drama performances were analyzed that performed in preschool and kindergartens during 2005-2008. The data of this study were based on video recorded during performances with a permission of the drama teachers.Seven drama performances have been categorized and evaluated by four drama specialists. Categories were analyzed under four -positive, negative, mixed and natural- emotional direction analysis. Four experts have evaluated the performances both as group and separately for derive reliability and validity of the study. As a result, these seven drama performances has been found as positive regarding to fluency of play, participation of all players, subject of the play, internal intervention, gaps in play and participation of leader. The seven drama performances have been found as negative regarding to being based on memorization, being absence or not of improvisation and didactic. The performances were categorized as mixed in terms of harmony between dances in plays, convenience of performers, play's language, body language, and the message of the play.This research is a pre-study of these seven drama performances' visual and linguistic content analysis.
\end{abstract}

Keywords: Drama in education, drama performances

\footnotetext{
${ }^{1}$ Öğr.Gör.Dr, Ankara Üniversitesi Eğitim Bilimleri Fakültesi, okvuran@education.ankara.edu.tr
} 


\section{Giriş}

Eğitimde dramanın çocuğun iletişim becerilerini, sosyalleşmesini, özgüvenini, kendisini ifade edebilmesini, yaratıcıllğını vb. pek çok özelliğini geliştirdiği kabul edilir (McCaslin, 1990). Çocuğun erken yaşta eğitimi bu becerilerin gelişimini hızlandıracaktır.

Ankara'daki anaokullarında, ana sınıflarında ya da sanat eğitimi veren kuruluşlarda drama, neredeyse vazgeçilemez bir etkinlik türünü oluşturmaktadır.

Okulöncesinde drama alanındaki temel kabuller şunlardır:

- Drama eğitimi 5-6 yaşlarından itibaren başlar

- Drama eğitiminde kostüme, dekora vb. gerek yoktur.

- Dramada seyirci yoktur. Oyuncu ve seyirci aynı kişilerden oluşur.

- Dramada gösteri amaçlanmaz.

- Dramaya herkesin katılımı esastır.

Bu kabullerden özellikle "dramada gösteri amaçlanmaz" ideasını "görünen dünyada aramak" realist bir bakış olamaz mı? 1980'li yıllardan beri drama etkinliklerine katıldım ve çoğunda da bir gösteri gerçekleşti. Drama eğitiminin olduğu her yerde özellikle de okulöncesinde ya da ilköğretim okullarında drama gösterilerinin de yapıldığı bir gerçektir. Ancak yapılan drama gösterisi şöyle bir sorucu/niyeti içermemelidir. "5 yaş grubu öğrencilerinin hazırladığı Küçük Kemal adlı drama gösterisi seyircileri gözyaşına boğdu” (Ses TV, 24.3.2008)

Amaç
$\mathrm{Bu}$ araştırmanın temel amacı Ankara'daki anaokullarındaki drama gösterilerinin genel bir değerlendirmesini yaparak ölçütler oluşturmak ve bu ölçütlerin olumlu, olumsuz, karışık ve nötr olarak duygusal yön analizini yapmaktır (Tavşancıl ve Aslan, 2001)

\section{Önem}

$\mathrm{Bu}$ araştırma dörtlü bir araştırmanın üçüncüsünü oluşturmaktadır. Birinci çalışma okulöncesi dönem çocuklarının drama etkinliklerine ilişkin görüşlerini içermekteydi (Okvuran, 2004) İkinci çalışma Ankara'daki çocuk tiyatrolarının içerik analiziyle değerlendirmekti (Okvuran, Tavşancıl ve İlhan, 2006). Dördüncü çalışma ise okulöncesindeki drama gösterilerinin içerik analizini içerecektir. Literatürde çocuk tiyatrolarının ve drama gösterilerinin içerik analizine ilişkin bir çalışmaya rastlanmamıştır. Çalışmaların Ankara'daki drama gösterileri ve çocuk tiyatrolarına ilişkin tartışma ve işbirliğini geliştirmeye katkı sağlayacağı umulmaktadır.

\section{Sayıltılar}

Araştırmanın analizleri dört ayrı araştırmacı tarafından yapılmış ve çocukların yaptı̆̆ 1 drama gösterilerini değerlendirip kategoriler oluşturulmuştur. Belirlenen kategorilere göre oyunlar olumlu, olumsuz, karışık ve nötr olarak değerlendirilmiştir. Analizlerin nesnel ve sistematik olduğu ve elde edilen sonuçların geçerli ve güvenilir olduğu söylenebilir.

\section{Sinırlılıklar}

Araştırmanın çalışma grubunu Ankara'da 2005-208 yılları arasında 5-6 yaş çocuklarıyla gerçekleştirilen gösterileri oluşturmaktadır. Herbiri drama öğretmeninin izniyle video kayıtları alınarak yapılmıştır. Bu araştırma, okulöncesi dönemdeki drama gösterilerinin içerik analizi için ön çalışma niteliğindedir.

Toplam yedi drama gösterisi incelemeye alınmıştır. 


\section{Tanımlar}

5-6 yaş çocuklarının yaptığı drama gösterilerinin analizinde aşağıdaki kategoriler kullanılmıştır:

1. Oyunun akışı : Oyun akışının canlı ve dinamik ya da ağır ve sıkıcı olup olmaması kastedilmektedir.

2. Oyunun ezbere dayalı olması : Oyunun bütününün hazır bir metne ve ezberlenmiş rollere dayalı olup olmaması

3. Oyuncuların hep birlikte katılarak oynaması : Oyuncuların içtenlikle katılarak oynayıp oynamadikları.

4. Dansların konuya uygunluğu : Oyundaki dansların oyunun içeriğiyle örtüşmesi.

5. Oyuncuların sahnedeki rahatlığı : Oyuncular oyun sırasında gerginlik, sıkıntı ya da utangaçlık yaşayıp yaşamadıkları.

6. Doğaçlamaya dayalı oyunculuk : Oyunda doğaçlamaya dayalı oyunculuk anlayışının olup olmadığı.

7. Oyunun ciddiyeti : Oyuncular sahnede ciddiyet içinde mi oynuyorlar ya da oyunun dışında mı hissediyorlar?

8. Oyunun konusu : Doğa sevgisi, hayvan sevgisi, ünlü masal kahramanları vb.

9. Oyunun konusunun çocuğa uygunluğu : Oyun için seçilen konuların çocuğun gelişim düzeyine uygun olup olmamas1.

10. Oyunun dilinin çocuğa uygunluğu : Oyundaki konuşmaların Türkçe dil kurullarına ve çocuğun gelişim düzeyine uygunluğu.

11. Oyundaki boşluklar : Oyun içinde aksaklıklar, sıkıcı boşluklar, anlar yada karışıklıklar olup olmamas1.

12. Sahneye giriş çıkışlar : Sahneye aynı ya da farklı yerlerden girip çıkılması.

13. Oyuncuların bedenini kullanabilmesi : Oyuncuların bedenlerini uygun ve etkili biçimde ifade edebilmeleri.

14. Seyircinin ciddiyeti : Seyircinin oyun sırasında sahneye laf atması, ya da tepkilerde aşırılık oyunun ciddiyetini etkileyebilir.

15. Oyun içinde müdahale : Gösterim anında oyun dışında bulunan kişilerin, yetişkinlerin oyuna müdahalesi.

16. Müziğin konuya uygunluğu : Seçilen müziklerin oyunun içeriğiyle örtüşmesi.

17. Kostümün oyuna uygunluğu : Seçilen kostümlerin içerikle örtüşmesi.

18. Dekor ve Aksesuar : Seçilen dekor ve aksesuarların konuyla örtüşmesi.

19. Odaktan Kopma : Oyunda konuyla bağlantısız durumların, anların yer alması.

20. Oyunun mesajı : İçerikte doğa sevgisi,yardımseverlik vb mesajların yer alması, vurgulanmasi.

21. Didaktiklik : Oyundaki mesajların didaktik, öğretisel bir dille vurgulanması.

22. Liderin/öğretmenin oyuna katılımı : Öğretmenin oyunun içinde yer alıp almaması.

\section{Yöntem}

\section{Araştırma Modeli}

İçerik analizi sözel ve yazılı verilerin belirli bir problem veya amaç bakımından sınıflandırılması, özetlenmesi, belirli değişken veya kavramların ölçülmesi ve belirli bir anlam çıkarılması için taranarak kategorilere ayrılmasıdır (Fox, 1969, akt. Tavşancıl ve Aslan, 2001). Bu araştırmada da çocukların yaptığ 1 drama gösterileri duygusal yön analizi tekniği ile drama gösterilerinin taşıması gereken özellikler açısından incelenmiştir. 


\section{Çalışma Grubu}

Ankara'da 2005-2008 yılları arasında 5-6 yaş çocuklarıyla okulöncesi eğitim kurumlarında gerçekleştirilen yedi drama gösterisi araştırmanın çalışma grubunu oluşturmaktadır.

\section{Verilerin Toplanması}

Araştırmada 5-6 yaş drama gösterileri araştırmacı ya da drama öğretmenleri tarafından kaydedilen video kayıtları kullanılarak yapılmıştır. İçerik analizinde belirlenen ölçütler drama alanında kuram ve uygulamada deneyimli dört uzmanın görüşleri, gözlemleri ve literatürdeki kabullerden ve video kayıtlarının analizinden yola çıkılarak belirlenmiştir.

5-6 yaş çocuklarının yaptığı drama gösterilerinin değerlendirilmesinde kullanılan ölçütler aşağıda belirtilmiştir.

\section{Drama Gösterilerinin Değerlendirilmesi}

- Oyunun akış1

- Oyunun ezbere dayalı olmas1

- Oyuncuların hep birlikte, katılarak oynamasi

- Danslarin konuya uygunluğu

- Oyuncuların sahnedeki rahatlığ1

- Doğaçlamaya dayalı oyunculuk

- Oyunun ciddiyeti

- Oyunun konusu

- Oyunun konusunun çocuğa uygunluğu

- Oyunun dilinin çocuğa uygunluğu

- Oyundaki boşlukların çocuğa uygunluğu

- Sahneye giriş çıkışlar

- Oyuncuların bedenini kullanabilmesi.

- Seyircinin ciddiyeti

- Oyun içinde müdahale

- Müziğin oyuna uygunluğu

- Kostümün oyuna uygunluğu

- Dekor ve aksesuarın oyuna uygunluğu

- Oyunda odaktan kopma

- Oyunun mesaj1

- Oyunda didaktiklik

- Liderin oyuna kat1limı

\section{Verilerin Analizi}

Araştırmada duygusal yön analizi tekniği kullanılarak (Tavşancıl ve Aslan 2001) 5-6 yaş çocuklarının yaptığı drama gösterileri taşıması gereken ölçütlere uygun ise olumlu, değilse olumsuz, hem olumlu hem olumsuz özellikler taşıyorsa karışık, ne olumlu ne de olumsuz özellikler taşımıyorsa nötr olarak değerlendirilmiştir. Araştırma drama gösterilerinin içerik analizi için ön çalışma niteliğindedir. Dolayısıyla bulgular ipucu sayılabilecek nitelikte kabul edilmiş̧ir.

\section{Bulgular ve Yorumlar}

Araştırmada 5-6 yaş çocuklarıyla gerçekleştirilen yedi drama gösterisi değerlendirilmiş ve aşağıdaki bulgulara ulaşılmıştır:

1. Oyunun akışı : Dört oyun olumlu, bir oyun karışık, iki oyun olumsuzdur. 
2. Oyunun ezbere dayalı olması : Bir oyun olumlu, üç oyun karışık, üç oyun olumsuzdur.

3. Oyuncuların hep birlikte katılarak oynaması : Dört oyun olumlu, üç oyun karışıktır.

4. Dansların konuya uygunluğu : Bir oyun olumlu, üç oyun karışıktır. Üç oyunda dans yoktur.

5. Oyuncuların sahnede rahatlığı : Dört oyun olumlu, iki oyun olumsuz, iki oyun karışıktır.

6. Doğaçlamaya dayalı oyunculuk : bir oyun olumlu, üç oyun olumsuz, üç oyun da karışıktır.

7. Oyunun ciddiyeti : Dört oyun olumlu, bir oyun karışık, iki oyuna karar verilememiştir.

8. Oyunun konusu : Dört oyun olumlu, üç oyun karışıktır.

9. Konunun çocuğa uygunluğu : İki oyun olumlu, üç oyun karışık, iki oyun olumsuz, bir oyun nötr bulunmuştur.

10. Oyunun dili : Bir oyun olumlu, iki oyun karışık, üç oyunda sözel dil yoktur.

11. Oyunda boşluklar : Dört oyun olumlu, iki oyun karışık, bir oyun olumsuzdur.

12. Sahneye giriş çıkışlar : Bir oyun olumlu, dört oyun karışık, bir oyun olumsuz, bir oyun nötr bulunmuştur.

13. Oyuncuların bedenini kullanması : Bir oyun olumlu, beş oyun karışık, bir oyun nötr bulunmuştur.

14. Seyircilerin ciddiyeti : Bir oyun olumlu, beş oyun karış1k, bir oyun olumsuzdur.

15. İçeriden müdahale : Üç oyun olumlu, iki oyun karışı, iki oyun olumsuzdur.

16. Müziğin uygunluğu : Üç oyun olumlu, bir oyun olumsuz, üç oyunda müzik yoktur.

17. Kostümün konuya uygunluğu : üç oyun olumlu, üç oyun karışık, bir oyun olumsuzdur.

18. Dekor ve aksesuarın uygunluğu : Bir oyun olumlu, iki oyun karışık, üç oyun nötr bulunmuştur.

19. Odaktan kopma : İki oyun olumlu, üç oyun karışık, bir oyunda uzlaşılamamıştır.

20. Oyunun mesajı : Bir oyun olumlu, beş oyun karışıtır.

21. Oyunda didaktiklik : Bir oyun olumlu, dört oyun karışık, iki oyun olumsuzdur.

22. Liderin katılımı : Üç oyun olumludur, dört oyunda lider yoktur.

Araştırma amacı doğrultusunda yedi oyun genel değerlendirildiğinde,

* Oyunun akışı, oyuncuların katılarak oynaması, oyuncuların sahnedeki rahatlığı, oyunun konusunun seçimi, oyunda boşluklar olmaması, oyuna içeriden müdahale olmaması, müzik ve kostümlerin seçimi ve liderin katılımı açısından olumlu bulunduğu,

* Oyunun ezbere dayalı olması, doğaçlamaya dayalı oyunculuğun yer alması, sahneye giriş çıkışlar, açısından olumsuz bulunduğu,

* Dansların konuya uygunluğu, oyunun konusunun çocuğa uygunluğu, oyunun dili, seyircinin ciddiyeti, oyuncuların bedeninin kullanması, kostüm, dekor ve aksesuarın oyuna uygunluğu, oyunun mesajı, odaktan kopma açılarından karışık olduğu anlaşılmaktadır.

\section{Sonuç ve Öneriler}

Araştırmadaki oyunlar değerlendirildiğinde ezbere dayalı oyunculuğun gerçekleştiği, dansların ve müziğin oyunlarda kısmen kullanıldığı, oyun mesajlarının karışık olduğu, anlaşılamadığı, kostüm ve dekor ve aksesuarda daha dikkatli olunması gerektiğine inanılmaktadır.

Araştırma dörtlü bir araştırmanın üçüncüsünü oluşturmaktadır. Okulöncesi dönem çocuklarının drama derslerine ilişkin görüşlerini içeren bir çalışmada (Okvuran, 2004), dramayı eğlenceli ve mutluluk sağlayan bir etkinlik olarak gördükleri anlaşılmaktadır. Drama eğitim sürecinin drama 
gösterim sürecinden bağımsız olduğu tahmin edilmektedir. Bu konuda daha ileri araştırmalar için hem çocuklarla ve hem de drama öğretmenleriyle görüşme yapmaya gereksinim olduğuna,

* Drama gösterilerinin içerik analiziyle söz ya da eylemin birim olarak ele alınarak değerlendirileceği ileri bir çalışmaya gereksinim olduğuna,

* Dramadaki gösterim süreçlerinde tiyatro alan bilgisi ve deneyimlerinden yararlanmaya,

* İdeal olarak dramanın gösterisinin olmamasına ancak bir gösterim olacaksa da doğaçlamadan, spontanlıktan, eğlenceden ve içtenlikten oluşturabilmenin gerekliliğine inanılmaktadır.

\title{
Kaynaklar
}

McCaslin, N.(1990). Creative drama in the classroom. California: Longman:

Tavşanc1l, E., ve Aslan, A. (2001). İ̧̧erik analizi ve uygulama örnekleri. İstanbul: Epsilon Yayıncilik.

Okvuran, A. (2004). Okul öncesi eğitim kurumlarındaki drama gösterilerinin değerlendirilmesi. 4. Ulusal Çocuk Kültürü Kongresi. Ankara: Ankara Üniversitesi Basımevi.

Okvuran, A., Tavşancıl, E., ve İlhan, A. (2006). Çocuk tiyatroları, içerik analizi, Ankara ili örneği. 2. Ulusal Çocuk Edebiyatı Sempozyumu. Ankara: Ankara Üniversitesi Basımevi.

Fox, D. (1969). The research process in education. Holt: Rinehart.

\section{Summary}

\section{Evaluation of Drama Performances}

\author{
Ayşe OKVURAN \\ Ankara Üniversitesi ${ }^{2}$
}

\section{Introduction}

Drama is an indispensable activity in pre-kindergarten and kindergarten classes and in institutions where art education is provided.

The main purpose of this study is to set some criteria by making a general evaluation of the drama performances in the kindergartens in Ankara and to make an emotional direction analysis of these criteria by categorizing them into four divisions: positive, negative, mixed and neutral(Tavşancıl and Aslan 2001).

This study is the third of a series of four studies. The first study included the opinions of the preschool children regarding drama activities. The second study made an evaluation of the children's theaters in Ankara by analyzing their contents. The fourth study is going to be about the content analysis of the drama performances of preschool level. No studies regarding the content analysis of the children's theaters and drama performances have been observed so far. These studies hope to contribute to the development of the cooperation and discussions pertaining to children's theaters/plays and drama performances in Ankara.

The study group of this research consists of the performances of the 5-6 year age group children in Ankara between the years 2005-2008. Each performance has been videotaped upon the permission given by the drama teacher. This study forms a pre-study of the content analysis of the preschool drama performances. The total number of the performances that have been analyzed is seven.

\footnotetext{
${ }^{2}$ Öğr.Gör.Dr, Ankara Üniversitesi Eğitim Bilimleri Fakültesi, okvuran@education.ankara.edu.tr
} 


\section{Research Method}

\section{Methodology}

Content analysis is dividing the written or oral data into categories by scanning them so that researchers can classify them in terms of a given problem or purpose, summarize them, measure specific variables or concepts and infer a meaning (Fox,1969). In this study, too, the drama performances of children have been examined in terms of the characteristics that a drama performance should have by using the emotional analysis technique.

\section{Study Group}

The study group of this research consists of the performances of the 5-6 year age group children in Ankara between the years 2005-2008.

\section{Collection of the Data}

The videos of the 5-6 year old children's drama performances taped by the researchers or drama teachers have been used in the study. The criteria determined in the content analysis have been set by referring to the opinions of the four experts experienced in the theory and application of the field of drama, their observations, acknowledgements in literature and the analyses of the video tapes.

Below are the criteria used in the evaluation of the drama performances made by 5-6 years old children.

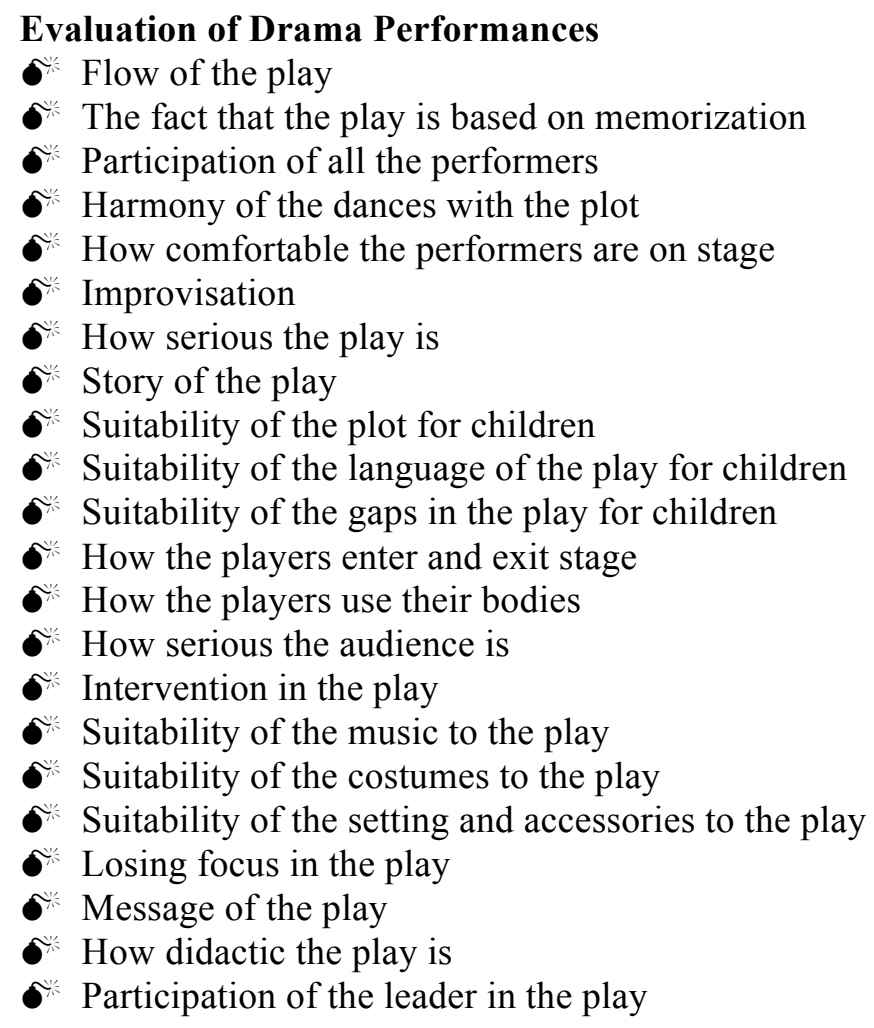

\section{Analysis of the Data}

In the study, the drama performances of the 5-6 year age group have been categorized by using the emotional direction technique (Tavşancıl and Aslan 2001). If the performances meet the criteria that a performance should have it has been classified as positive, if it does not it has been classified as negative, if it has both positive and negative characteristics it has been classified as mixed and if it has neither positive nor negative characteristics it has been classified as neutral. This study is a pre-study for the content evaluation of drama performances. Therefore, these data have been considered as clues for further studies.

\section{Results}


When the seven drama plays are evaluated in relation with the purpose of the study,

- they have proven to be positive in terms of the flow of the play, participation of all the performers, how comfortable the performers are on stage, the choice of the story of the play, the fact that there were no gaps in the play, the fact that there was no internal intervention in the play, the choice of music and costumes and participation of the leaders in the play

- they have proven to be negative in terms of the fact that the plays rely on memorization, the fact that there is improvisation in them and the entries and exits in the play

- they have proven to be mixed in terms of the suitability of the dances to the story, suitability of the plot for children, language of the play, seriousness of the audience, how the players use their bodies, suitability of the settings, costumes and accessories to the play, message of the play and loss of focus.

\section{Conclusion and Suggestions}

In a study about the opinions of preschool children regarding drama lessons (Okvuran, 2004) it was found out that these children consider drama an enjoyable and fun activity. It is thought that education process of drama is independent of performance of drama. Therefore, it is necessary to

- hold interviews both with the students and the drama teachers

* to carry out a further study in which words are acts are going to be evaluated by being considered as units through content analysis

- make use of experiences and knowledge in the field of drama throughout the process of performances

if there is going to be a drama performance, create one which includes elements of improvisation, spontaneity, fun and sincerity. 